\title{
Influence of mussel aquaculture on sediment organic enrichment in a nutrient-rich coastal embayment
}

\author{
B. T. Hargrave*, L. I. Doucette, P. J. Cranford, B. A. Law, T. G. Milligan \\ Ecosystem Research Division, Department of Fisheries and Oceans, Bedford Institute of Oceanography, 1 Challenger Dr., \\ PO Box 1006, Dartmouth, Nova Scotia B2Y 4A2, Canada
}

\begin{abstract}
Effects of mussel Mytilus edulis aquaculture on benthic organic enrichment were determined in Tracadie Bay, a shallow, nutrient-rich embayment in Prince Edward Island, Canada. Water content (WC), inorganic grain size (GS), organic matter (OM), redox potentials $\left(\mathrm{Eh}_{\mathrm{NHE}}\right)$ and free sulfides (S) in the upper $2 \mathrm{~cm}$ of sediment were measured at 58 stations throughout the inlet to evaluate spatial variations between lease and non-lease locations. MANOVA results showed that mean $( \pm \mathrm{SD})$ values for WC $(64.8 \pm 12.7 \%), \mathrm{OM}(9.8 \pm 4.3 \%)$, and S $(1794 \pm 771 \mu \mathrm{M})$ were significantly $(\mathrm{p}<0.005)$ higher and $\mathrm{Eh}_{\mathrm{NHE}}$ lower $(-51 \pm 78 \mathrm{mV})$ within mussel leases $(\mathrm{n}=24)$ vs. non-lease areas $(\mathrm{n}=34)$. Negative regressions between $\mathrm{S}$ and GS and positive regressions between $\mathrm{Eh}_{\mathrm{NHE}}$ and GS at lease and non-lease locations had similar slopes but intercept values were significantly higher for $\mathrm{S}$ and lower for $\mathrm{Eh}_{\mathrm{NHE}}(\mathrm{p}<0.007)$ for lease locations. Eh $\mathrm{h}_{\mathrm{NHE}}$ and a Benthic Enrichment Index derived from $\mathrm{Eh}_{\mathrm{NHE}}$ $\mathrm{OM}$ and WC were inversely related to $\mathrm{S}$. K-means clustering and multi-dimensional scaling showed that geochemical variables could be used to group stations into categories of benthic organic enrichment within mussel lease and non-lease areas characteristic of oxic-hypoxic sediments described by measures of $\mathrm{S}$ and $\mathrm{Eh}_{\mathrm{NHE}}$.
\end{abstract}

KEY WORDS: Sulfides $\cdot$ Redox potentials $\cdot$ Hypoxic $\cdot$ Anoxic $\cdot$ Biodeposition $\cdot$ Mytilus edulis

\section{INTRODUCTION}

There is ample evidence that marine bivalve aquaculture can alter coastal ecosystem processes (Newell 2004), but demonstrations of effects on sediment chemical variables and macrofauna communities have been inconsistent. Benthic effects appear to reflect sitespecific differences in hydrographic and physical factors that influence particulate matter deposition and organic matter accumulation in sediments (Hatcher et al. 1994, Grant et al. 1995, Crawford et al. 2003, Anderson et al. 2005, Miron et al. 2005). Where currents are weak or water depth is shallow, biodeposition due to mussel feeding activity would be expected to contribute to the formation of hypoxic conditions in sediments, due to higher organic matter sedimentation. Such effects have been observed or inferred from models in Tracadie Bay,
Prince Edward Island (PEI) (Grant et al. 2005, 2007a,b, Waite et al. 2005, Cranford et al. 2007) and other inlet systems (Dame \& Prins 1997, Chamberlain et al. 2001).

Previous studies to examine impacts of long-line mussel aquaculture on sediments have sampled a relatively small number of sites within and adjacent to leases (Chamberlain et al. 2001, Crawford et al. 2003, Miron et al. 2005). Our objective was to test the hypothesis that increased biodeposition from Mytilus edulis aquaculture in Tracadie Bay results in benthic organic enrichment, which, depending on factors such as bathymetry and currents, may be detected at either a local or bay-wide scales. Selected sediment geochemical variables known to be sensitive to organic matter accumulation and the formation of hypoxic or anoxic conditions in sediments were measured spatially to detect benthic enrichment effects. 


\section{MATERIALS AND METHODS}

Study site. A physical description of Tracadie Bay has been provided by Gregory et al. (1993), Dowd et al. (2001), Dowd (2003, 2005) and Grant et al. (2005). The inlet is located on the western shore of PEI, with an opening allowing tidal exchange with the southern Gulf of St. Lawrence (Fig. 1). High and low tide area is 19.0 and $13.8 \mathrm{~km}^{2}$, respectively, with mean and maximum depths of 2.5 and $6 \mathrm{~m}$. Tracadie Bay accounts for approximately $10 \%$ of the total PEI mussel production. The long-line mussel aquaculture industry in PEI expanded rapidly in the 1990 s, increasing by $43 \%$ between 1997 and 2001 and stabilizing at approximately 17000 t yr $^{-1}$ after 2000 (Statistics Canada 2005). Tra-

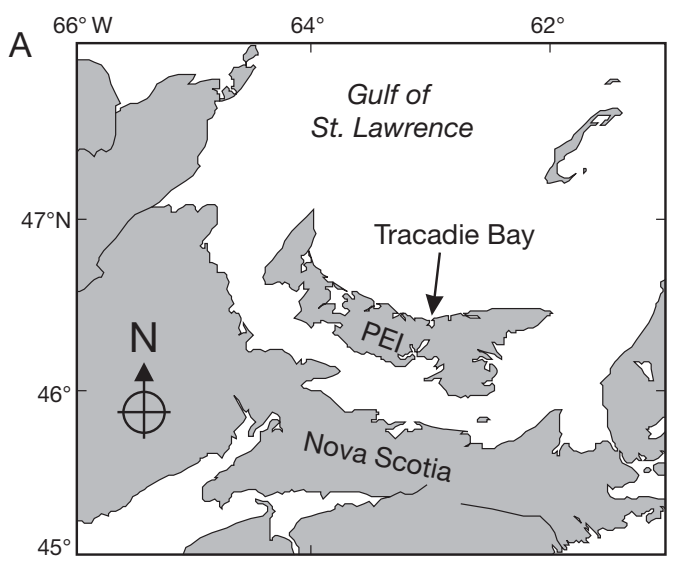

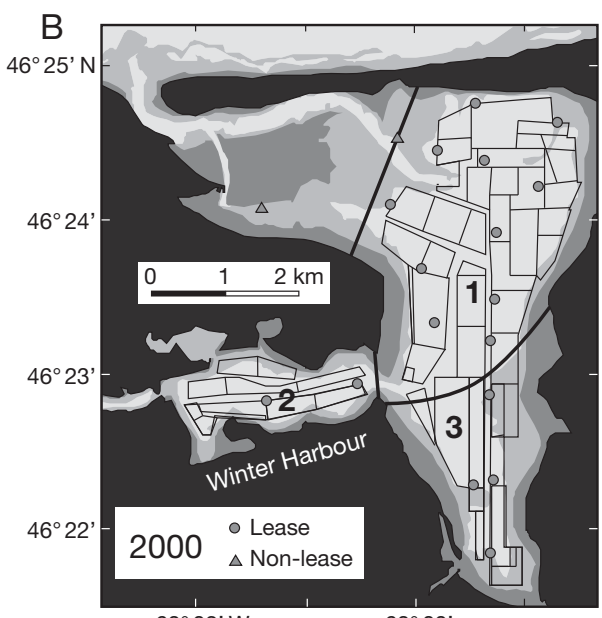

$63^{\circ} 02^{\prime} \mathrm{W}$

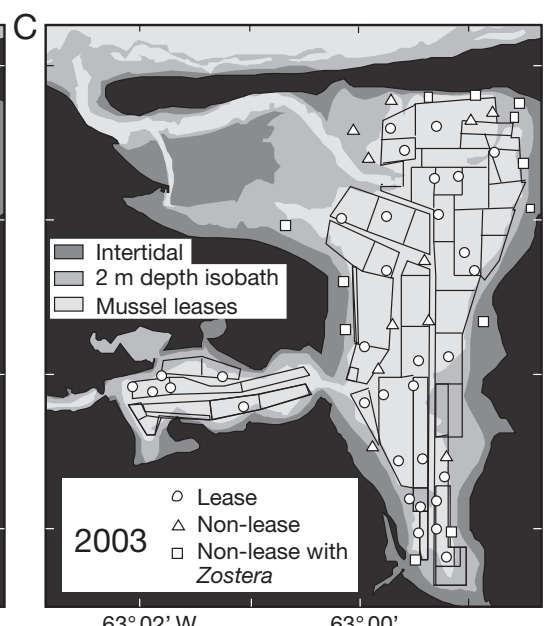

$63^{\circ} 02^{\prime} \mathrm{W}$ cadie Bay, with an annual yield of $\sim 2000 \mathrm{t} \mathrm{yr}^{-1}$, is the most intensively leased mussel aquaculture embayment in PEI. Mussel leases occupy approximately $7 \mathrm{~km}^{2}(\sim 50 \%$ of low tide area) of the total inlet area. Mussels are grown for approximately 24 mo starting in the summer with harvesting completed by the fall of the second year. Leases therefore contained mussels $<1$ and $>1$ yr old during our study.

Mixed diurnal and semi-diurnal tides $(<1 \mathrm{~m}$ elevation) flow primarily along the long axis of the bay (mean currents $<0.5 \mathrm{~cm} \mathrm{~s}^{-1}$ ) with stronger flushing near the mouth. Water volume at mean tide is $36 \times$ $10^{6} \mathrm{~m}^{3}$ and water exchanges $\left(\sim 500 \mathrm{~m}^{3} \mathrm{~s}^{-1}\right)$ with the Gulf of St. Lawrence. Water residence time based on tidal prism analysis is about $4 \mathrm{~d}$. Freshwater input is small $\left(<1 \mathrm{~m}^{3} \mathrm{~s}^{-1}\right.$ during summer) and occurs primarily into Winter Harbour (Fig. 1). The Winter River watershed (approximately $70 \mathrm{~km}^{2}$ ) includes forested (47\%) and agricultural (33\%) lands used for potato, grain and hay crops (Cranford et al. 2007).

Sample collection. A differential GPS (DGPS) tracking system recorded sampling locations. Sampling was carried out at 58 stations between July 8 and 17, 2003 using 2 replicate Ekmann grabs $(15 \times 15 \mathrm{~cm})$ (Fig. 1). Immediately after collection, surface water from grabs was removed by siphon. The presence of seagrass Zostera marina (henceforth Zostera) white sulfur (Beggiatoa spp.) bacterial mats and the odour of $\mathrm{H}_{2} \mathrm{~S}$ were noted. Surface sediment was collected using duplicate $5 \mathrm{ml}$ cut-off syringes filled by slowly withdrawing the barrel as the open end was pushed laterally across the 0 to $2 \mathrm{~cm}$ surface layer. Each sample was considered to include a homogenous mixture of sediment from the upper $2 \mathrm{~cm}$ surface layer due to topographic irregularities of the sediment-water interface. Syringes were completely filled with sediment and sealed using plastic caps to avoid exposure to air and stored on ice until analysis (12 to $24 \mathrm{~h}$ ). An additional sample of 0 to $2 \mathrm{~cm}$ surface sediment in grabs was taken by spatula and placed in a scintillation vial or Whirl Pack bag for inorganic grain size analysis.

Sample analysis. Methods described in Kranck \& Milligan (1979) and Milligan \& Kranck (1991) to determine modal inorganic grain size (GS, $\mu \mathrm{m})$ consisted of digestion of sediment in excess $35 \% \mathrm{H}_{2} \mathrm{O}_{2}$ to remove organic matter (OM) followed by resuspension in $1 \% \mathrm{NaCl}$. Samples were disaggregated using a sapphire tipped ultra-

Fig. 1. (A) Study area, Prince Edward Island (PEI). (B,C) Sampling locations in lease boundaries. (b) Locations sampled by Miron et al. (2005) in November 2000 and box model regions (areas numbered 1-3 separated by heavy black lines) described in Dowd (2005). Grey circles $(n=17)$ : lease sites; grey triangles $(n=2)$ : non-lease sites. $(C)$ Stations sampled between July 9 and 17 , 2003 (duplicate Ekmann grabs). Circles: stations within or on lease boundaries; triangles: non-lease locations $>25 \mathrm{~m}$ from leases; squares: non-lease sites where Zostera marina was present 
sonic probe before counting on a Multisizer (IIE, Coulter). Up to 4 aperture tubes $(30,200,400$ and $1000 \mu \mathrm{m})$ were used, yielding a size range of 0.8 to $500 \mu \mathrm{m}$. Results were expressed as equivalent weight percent calculated from the volume analyzed, assuming a specific gravity of $2650 \mathrm{~kg} \mathrm{~m}^{-3}$ and normalized to $100 \%$. Particle size spectra were plotted as log equivalent weight $(\%)$ vs. log diameter to preserve the shapes of the distributions over a wide range of concentrations. GS was derived from the Coulter Counter output.

Redox potentials $\left(\mathrm{Eh}_{\mathrm{NHE}}\right)(\mathrm{mV})$ were determined on $2.0 \mathrm{ml}$ of sediment extruded from syringes into a $50 \mathrm{ml}$ plastic beaker using methods described in Wildish et al. (1999). Syringes were re-capped and re-refrigerated $\left(5^{\circ} \mathrm{C}\right)$ for further analyses described below. The extruded sample was homogenized with a glass rod, temperature was measured and $\mathrm{Eh}_{\mathrm{NHE}}$ determined immediately using a Pt ion-specific combination electrode (Orion 96-78-00) containing an $\mathrm{Ag} / \mathrm{AgCl}$ reference electrode filled with 4M KCL (Orion 900011) connected to an Accumet (AP25) multimeter (Fisher Scientific).

Newly purchased electrodes ( $<6$ mo old) were used to avoid poisoning of the Pt tip, which was routinely cleaned with an abrasive strip (Wildish et al. 2004). Potentials usually stabilized within 1 to 3 min and there was not noticeable effect of exposure to air during the brief period of measurement. When stable readings were not obtained rapidly, possibly due to poorly formed junction potentials, a value was recorded when drift decreased to $<10 \mathrm{mV} \min ^{-1}$ (usually $<5 \mathrm{~min}$ ). $\mathrm{Eh}_{\mathrm{NHE}}$ was calculated by addition of the normal hydrogen electrode (NHE) potential of the reference electrode at the sample temperature as described in Wildish et al. $(1999,2004)$.

Water content (WC) and OM (\% of sediment dry weight) were determined using $1.0 \mathrm{ml}$ of wet sediment representative of the 0 to $2 \mathrm{~cm}$ layer extruded from a syringe into a pre-weighed scintillation vial. Vials were tightly capped to prevent dehydration until weighed using a Mettler AE balance $( \pm 0.05 \mathrm{mg})$. WC was determined as percent weight loss after drying to a constant weight $\left(60^{\circ} \mathrm{C}, 24 \mathrm{~h}\right)$ and re-weighing. Samples were pulverized using a mortar and pestle, placed on a pre-ashed and pre-weighed piece of aluminum foil $\left(\sim 2 \mathrm{~cm}^{2}\right)$, combusted in an ashing oven $\left(550^{\circ} \mathrm{C}, 4 \mathrm{~h}\right)$ and $\mathrm{OM}$ calculated as percent weight loss.

Total free sulfide (S), defined as the sum of dissolved $\mathrm{H}_{2} \mathrm{~S}+\mathrm{HS}^{-}+\mathrm{S}^{2-}$ in a sediment slurry of equal volumes of sediment and an alkaline $(\mathrm{pH}=12)$ sulfide antioxidant buffer solution (SAOB) containing NAOH, EDTA and ascorbic acid (Thermo Electron Corp 2003), was measured using sediment remaining in each capped cutoff syringe. We extruded $2.0 \mathrm{ml}$ into a $50 \mathrm{ml}$ plastic beaker and added $2.0 \mathrm{ml}$ of SAOB. We used a glass stirring rod to mix the SAOB-sediment slurry and an Accumet AP25 meter with an Orion $\mathrm{Ag}^{+} / \mathrm{S}^{2-}$ combination ionplus ${ }^{\circledR}$ electrode (96-16BNWP) filled with Orion Optimum 'A' filling solution calibrated with $\mathrm{Na}_{2} \mathrm{~S} \cdot 9 \mathrm{H}_{2} \mathrm{O}(100,1000$ and $10000 \mu \mathrm{M} \mathrm{S})$ to determine S concentration (Wildish et al. 1999, Thermo Electron Corp 2003).

Stable readings with the $\mathrm{Ag}^{+} / \mathrm{S}^{2-}$ electrode were usually obtained within 1 to $2 \mathrm{~min}$. Exposure times $>2 \mathrm{~min}$ were avoided since solid phase metal-sulfide complexes may be solubilized in the presence of SAOB (Thermo Electron Corp 2003). Wildish et al. (1999) showed that stable concentrations of $\mathrm{S}$ were measured if potentials were read within a few minutes of mixing sediment and SAOB. S concentrations were expressed as $\mu \mathrm{M}$ based on sediment volume $(2.0 \mathrm{ml})$. Since $\mathrm{Ag}^{+} / \mathrm{S}^{2-}$ electrodes respond to free $\mathrm{S}$ ions dissolved in pore water, a corrected pore water concentration $\mathrm{S}_{\mathrm{pc}}\left(\mu \mathrm{M} \mathrm{ml}^{-1}\right)$ was calculated as

$$
\mathrm{S}_{\mathrm{pc}}=\mathrm{S} \div(\mathrm{WC} \div 100)
$$

Statistical analysis. Contour maps were created with Surfer 8 (Golden Software) to illustrate inlet-wide patterns in the distribution of geochemical variables. The kriging algorithm was used to create grid files that were then blanked with a digitized outline of the bay. Grid files were mapped for specified contour intervals as grayscale values. Contour mapping was only displayed for sampled areas; the large intertidal region and tidal channels near the mouth of Tracadie Bay, which were not sampled, were excluded (Fig. 1).

Univariate and repeated measures multivariate analysis of variance (MANOVA), linear regression and nonparametric clustering methods (Wilkinson 2000) were used to compare observations from lease and non-lease sampling locations. All regression equations reported were significant $(\mathrm{p} \leq 0.05)$. Four site categories (lease, non-lease without and with Zostera, and a spat collection area [Winter Harbour]) were compared using a 1-way MANOVA based on the Pillai Trace test statistic. Data were log-transformed $\left(\mathrm{Eh}_{\mathrm{NHE}}\right.$ was made positive by addition of $+200 \mathrm{mV}$ ) to achieve normality as confirmed from probability plots and Shapiro-Wilks tests. Equality of variance was confirmed from residual plots. When MANOVA results were significant, post-hoc multiple comparison tests were used to determine which dependent variables accounted for differences between site categories. Differences were detected using multivariate F-tests while the measured variables involved in a significant MANOVA were determined from univariate F-tests.

$Z$-score standardized values of $\mathrm{Eh}_{\mathrm{NHE}}, \mathrm{S}$ and $\mathrm{S}_{\mathrm{pc}}$ were used to group observations from 3 site categories (lease, non-lease and Winter Harbour) using K-means clustering. The method divides a set of objects into a selected 
number of groups by maximizing between-cluster relative to within-cluster variation. $Z$-score transformations removed effects of measurement scale and numbers of clusters were selected to maximize the average $F$ values. Tests using different numbers of groups (usually 3 or 4) were performed to obtain maximum $F$ values. Average values of $E h_{\mathrm{NHE}}$ and $\mathrm{S}$ for each cluster were compared with threshold values proposed for benthic organic enrichment classification of marine sediments based on these variables (Hargrave et al. 2008).

Non-metric multi-dimensional scaling (MDS) was used to detect similarities and differences between station location categories using untransformed values of GS, WC, OM, Eh $\mathrm{NHE}_{\mathrm{NH}} \mathrm{S}$ and $\mathrm{S}_{\mathrm{pc}}$. Dimensional coordinates in the analysis based on multivariate similarity between pairs of sampling stations represent dissimilarity-similarity as distance measures between points on an $X-Y$ plot. Axes in MDS plots are not labeled, since distance measures are relative not absolute numbers. Correlation matrices between different variables and the 2-dimensional co-ordinates based on Euclidean distances and a Kruskal loss function were used to determine the relative importance of different variables in separating sites within the multidimensional space.

Earlier comparisons of data for benthic variables around marine finfish and molluscan aquaculture sites showed that when organic carbon (OC) sedimentation rate (SR) was $>1 \mathrm{~g} \mathrm{C} \mathrm{m}^{-2} \mathrm{~d}^{-1}$ there was a positive relationship between $\log _{10}$ SR and sediment organic carbon (SOC) expressed as mol C m ${ }^{-2}$ in the surface $1 \mathrm{~cm}$ layer after correction for sediment WC (Hargrave 1994, Hargrave et al. 1997). In addition there was an inverse relation between $\mathrm{Eh}_{\mathrm{NHE}}$ and SOC. The relationships were used to derive a Benthic Enrichment Index (BEI)

$$
\begin{aligned}
\mathrm{BEI}= & (\{[(100-\mathrm{WC}) \div 100] \times 10000\} \times \\
& \{\mathrm{OC} \div 100\} \div 12) \times \mathrm{Eh}_{\mathrm{NHE}}
\end{aligned}
$$

Since OM and not OC was measured in our study a molar conversion of 36 rather than 12 was used to calculate $\mathrm{BEI}_{\mathrm{OM}}$ as

$$
\begin{aligned}
\mathrm{BEI}_{\mathrm{OM}} & =(\{[(100-\mathrm{WC}) \div 100] \times 10000\} \times \\
& \{\mathrm{OM} \div 100\} \div 36) \times \mathrm{Eh}_{\mathrm{NHE}}
\end{aligned}
$$

\section{RESULTS}

\section{Inlet-wide spatial patterns}

Summary statistics for stations in mussel lease areas, non-lease sites with and without Zostera, and Winter Harbour locations show site-related differences among the 4 types of sampling location (Table 1). The extensive distribution of mussel farms throughout Tracadie
Bay (Fig. 1) resulted in samples being collected within leases from water depths representing a range of depths (1 to $6 \mathrm{~m}$ ) that was slightly broader than that for non-lease locations ( 1 to $4.5 \mathrm{~m}$ ). Differences between lease and non-lease sites could therefore be due to bathymetry or other depth-dependent variables. The depth range at non-lease sites and in Winter Harbour was similar to that in lease and non-lease areas without Zostera, which was not present at any lease location. The depth for non-lease sites with Zostera was lower than for other station categories, reflecting the distribution of these sites around the perimeter of the inlet (Fig. 1).

Values for GS and WC at lease, non-lease sites without Zostera and all stations in Winter Harbour were not

Table 1. Summary statistics for water depth $(Z, \mathrm{~m})$, modal grain size $(\mathrm{GS}, \mu \mathrm{m})$, water content $(\mathrm{WC}, \%)$, organic matter $(\mathrm{OM}, \%)$, redox potentials $\left(\mathrm{Eh}_{\mathrm{NHE}}, \mathrm{mV}\right)$, total free sulfides on a sediment volume $(\mathrm{S}, \mu \mathrm{M})$ and pore water volume $\left(\mathrm{S}_{\mathrm{pc}} \mu \mathrm{M} \mathrm{ml} \mathrm{M}^{-1}\right)$ basis for surface $(0-2 \mathrm{~cm})$ sediment samples from 58 stations in Tracadie Bay collected July 9-17, 2003,

\begin{tabular}{|c|c|c|c|c|c|c|}
\hline Variable & Mean & Max. & Min. & $\mathrm{SE}$ & $\mathrm{SD}$ & $\mathrm{CV}$ \\
\hline \multicolumn{7}{|c|}{ Lease (L) $n=24$} \\
\hline$Z$ & 3.79 & 6.00 & 1.00 & 0.28 & 1.38 & 0.36 \\
\hline GS & 69 & 223 & 12 & 12 & 58 & 0.84 \\
\hline WC & 64.77 & 79.81 & 39.01 & 2.58 & 12.65 & 0.20 \\
\hline OM & 9.75 & 18.29 & 3.39 & 0.89 & 4.34 & 0.45 \\
\hline $\mathrm{Eh}_{\mathrm{NHE}}$ & -51 & +97 & -130 & 16 & 78 & 1.53 \\
\hline $\mathrm{S}$ & 1794 & 4220 & 855 & 157 & 771 & 0.43 \\
\hline $\mathrm{S}_{\mathrm{pc}}$ & 2733 & 5542 & 1508 & 182 & 892 & 0.33 \\
\hline \multicolumn{7}{|c|}{ Non-lease (NL) (no Zostera) n = 11} \\
\hline$Z$ & 3.36 & 4.50 & 1.50 & 0.32 & 1.38 & 0.41 \\
\hline GS & 78 & 169 & 16 & 15 & 58 & 0.74 \\
\hline WC & 58.33 & 75.88 & 33.39 & 1.13 & 3.77 & 0.23 \\
\hline OM & 7.20 & 13.83 & 1.92 & 3.76 & 4.34 & 0.52 \\
\hline $\mathrm{Eh}_{\mathrm{NHE}}$ & +76 & +159 & -47 & 18 & 60 & 0.79 \\
\hline $\mathrm{S}$ & 753 & 1230 & 385 & 82 & 272 & 0.36 \\
\hline $\mathrm{S}_{\mathrm{pc}}$ & 1305 & 1857 & 690 & 120 & 398 & 0.30 \\
\hline \multicolumn{7}{|c|}{ Non-lease (NLZ) (with Zostera) $\mathrm{n}=15$} \\
\hline$Z$ & 2.17 & 4.50 & 1.00 & 0.30 & 1.18 & 0.54 \\
\hline GS & 204 & 256 & 128 & 8 & 34 & 0.17 \\
\hline WC & 30.39 & 50.71 & 21.87 & 1.87 & 7.23 & 0.24 \\
\hline OM & 1.47 & 2.76 & 0.60 & 0.17 & 0.67 & 0.46 \\
\hline $\mathrm{Eh}_{\mathrm{NHE}}$ & +192 & +395 & +53 & 21 & 81 & 0.42 \\
\hline $\mathrm{S}^{\mathrm{Nat}}$ & 391 & 655 & 104 & 49 & 189 & 0.48 \\
\hline $\mathrm{S}_{\mathrm{pc}}$ & 1315 & 2554 & 395 & 168 & 653 & 0.50 \\
\hline \multicolumn{7}{|c|}{ Winter Harbor $(\mathrm{WH}) \mathrm{n}=8$} \\
\hline$Z$ & 3.56 & 4.50 & 3.00 & 0.18 & 0.50 & 0.14 \\
\hline GS & 57 & 223 & 12 & 25 & 71 & 1.25 \\
\hline WC & 71.34 & 80.33 & 29.54 & 6.05 & 17.11 & 0.24 \\
\hline OM & 12.40 & 15.49 & 1.88 & 1.54 & 4.36 & 0.35 \\
\hline$E h_{\mathrm{NHE}}$ & -32 & +127 & -116 & 31 & 87 & 2.72 \\
\hline$S^{1 N T L}$ & 1099 & 1460 & 713 & 98 & 278 & 0.25 \\
\hline $\mathrm{S}_{\mathrm{pc}}$ & 1608 & 2414 & 938 & 154 & 438 & 0.27 \\
\hline
\end{tabular}
grouped by 4 station categories. $n$ : sample number; SE: standard error; SD: standard deviation; CV: coefficient of variation, $\mathrm{SD} /$ mean 
significantly different $(p>0.05)$ (Table 1). However, sediments at non-lease sites with Zostera, generally located in more shallow water, were coarser and contained less water. Low mean values for $\mathrm{OM}, \mathrm{S}$ and $\mathrm{S}_{\mathrm{pc}}$ at stations with Zostera relative to other locations are consistent with larger modal grain size and more positive $\mathrm{Eh}_{\mathrm{NHE}}$.

Means $( \pm \mathrm{SD})$ for $\mathrm{OM}, \mathrm{S}$ and $\mathrm{S}_{\mathrm{pc}}$ were higher, and $\mathrm{Eh}_{\mathrm{NHE}}$ was lower in mussel leases relative to all nonlease stations (Table 1). While OM in sediment from Winter Harbour was higher than at lease sites, values for $\mathrm{S}$ and $\mathrm{S}_{\mathrm{pc}}$ were lower. Mean $\mathrm{Eh}_{\mathrm{NHE}}$ for stations in Winter Harbour was negative and similar to the average value for lease sites in contrast to generally positive potentials in non-lease locations. Based on coefficients of variation (CV), WC showed the least and $\mathrm{Eh}_{\mathrm{NHE}}$ the most variability in each site category. Variance in geochemical variables was most uniform for non-lease sites with Zostera.

The limited number of stations $(n=58)$ used to derive contour maps to indicate the broad spatial distribution of variables in the bay was insufficient to detect leasescale benthic effects. However, the extensive area in Tracadie Bay covered by leases required some consideration of the inlet-wide spatial distribution of variables. For example, maximum depths (4 to $6 \mathrm{~m}$ ) occurred in the NE corner of Tracadie Bay, where sediments were predominantly medium silt to very fine sand (GS $<50 \mu \mathrm{m}$ ) (Fig. 2A,B). Other variables showed a similar distribution pattern with high levels of $\mathrm{OM}, \mathrm{S}$ and $\mathrm{S}_{\mathrm{pc}}$ and low (negative) $\mathrm{Eh}_{\mathrm{NHE}}$ in deeper $(>4 \mathrm{~m}$ ) water within the bay and in Winter Harbour, where fine-grained sediments predominated (Fig. 2 $\mathrm{C}-\mathrm{F}$ ). Intermediate depths (2 to $4 \mathrm{~m}$ ) in the southern area of the bay and at the mouth of Winter Harbour were characterized by fine sand (100 to $200 \mu \mathrm{m})$ with lower concentrations of $\mathrm{OM}, \mathrm{S}$ and $\mathrm{S}_{\mathrm{pc}}$. Coarser sand in areas $<2 \mathrm{~m}$ depth around the perimeter of the Bay, where Zostera was often present (Fig. 1), generally contained the lowest concentrations of $\mathrm{OM}, \mathrm{S}$ and $\mathrm{S}_{\mathrm{pc}}$ observed. Beggiatoa mats, with a patchy distribution, were most prominent at stations $>4 \mathrm{~m}$ in depth within mussel leases, but also occurred at 2 stations closest to the head of Winter Harbour.

\section{Correlations between variables}

Pearson correlation coefficients showed expected correlations (generally $\mathrm{r}>0.6$ ) between geochemical variables (Table 2). Pearson correlation coefficients showed that GS was inversely correlated with $\mathrm{WC}, \mathrm{OM}$ and $\mathrm{S}$, and positively related to $\mathrm{Eh}_{\mathrm{NHE}}$ (Table 2).
Logarithmic transformations of GS and S improved correlations with $\mathrm{OM}$ and Eh, respectively. In general, Pearson coefficients for $\mathrm{S}_{\mathrm{pc}}$ with GS, WC, OM and Eh were lower $(r<0.54)$. High coefficients $(r>0.8)$ between $S$ and $S_{p c}$ reflect the calculation of $S_{p c}$ from $S$ (Eq. 1).

\section{Comparisons of station categories}

MANOVA results showed significant multivariate differences among the 4 station categories; post-hoc multiple comparisons indicated these differences involved effects of all 7 dependent variables (Table 3). $\mathrm{S}$ and $\mathrm{S}_{\mathrm{pc}}$ within mussel leases were the only variables significantly different when leases were compared to other sites categories. $\mathrm{Eh}_{\mathrm{NHE}}$ was significantly different between lease and non-lease locations, but not between lease and Winter Harbour sites. All 7 variables contributed to differences between lease and nonlease sites with Zostera and, with the exception of $\mathrm{S}_{\mathrm{pc}}$ to differences between all non-lease stations and Winter Harbour. Although $Z$ and GS were not significantly different between lease and non-lease sites without Zostera or between lease and Winter Harbour locations, these variables were significantly different in other location comparisons (e.g. 2 non-lease categories and Winter Harbour).

Plots of untransformed dependent variables for lease, non-lease and Winter Harbour locations showed significant inverse relationships between $\log$ GS and $Z$, WC, OM, and a positive relationship for $\mathrm{Eh}_{\mathrm{NHE}}$ as indicated by Pearson correlation coefficients for combined stations (Table 2) (Fig. 3A-D). Correlation coefficients were increased by log transformation of both GS and $\mathrm{S}$. While there was a trend to decreased $\mathrm{S}_{\mathrm{pc}}$ with increased GS the regression was not significant (Fig. 3E,F). Higher concentrations of $S$ and $S_{p c}$ at lease sites relative to other location categories shown in Table 1 is evident in Fig. 3F.

Despite the lack of a significant correlation with GS, $\mathrm{S}_{\mathrm{pc}}$ within leases was significantly higher than for com-

Table 2. Pearson correlation coefficients between arithmetic and logtransformed values of variables measured at 58 stations in Tracadie Bay July 9-17, 2003, described in Table 1

\begin{tabular}{|lrrrrrrr|}
\hline & GS & $\log \mathrm{GS}$ & $\mathrm{WC}$ & $\mathrm{OM}$ & $\mathrm{Eh}_{\mathrm{NHE}}$ & $\mathrm{S}$ & $\log \mathrm{S}$ \\
\hline $\mathrm{WC}$ & -0.947 & -0.913 & & & & & \\
$\mathrm{OM}$ & -0.881 & -0.919 & 0.957 & & & & \\
$\mathrm{Eh}_{\mathrm{NHE}}$ & 0.756 & 0.733 & -0.806 & -0.779 & & & \\
$\mathrm{~S}$ & -0.640 & -0.648 & 0.667 & 0.669 & -0.772 & & \\
$\log \mathrm{S}$ & -0.753 & -0.712 & 0.764 & 0.739 & -0.860 & & \\
$\mathrm{~S}_{\mathrm{pc}}$ & -0.343 & -0.340 & 0.322 & 0.341 & -0.538 & 0.891 & 0.811 \\
$\log \mathrm{S}_{\mathrm{pc}}$ & -0.380 & -0.355 & 0.348 & 0.367 & -0.633 & 0.811 & 0.866 \\
\hline
\end{tabular}



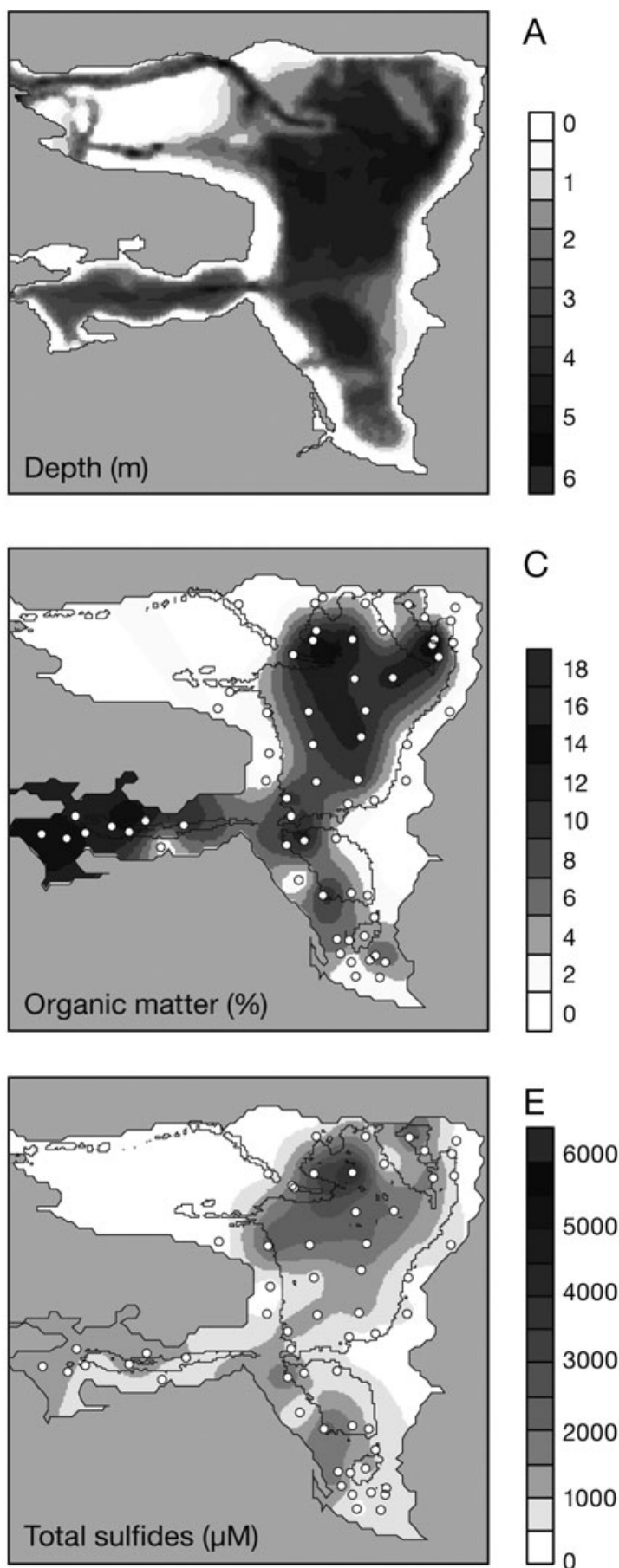

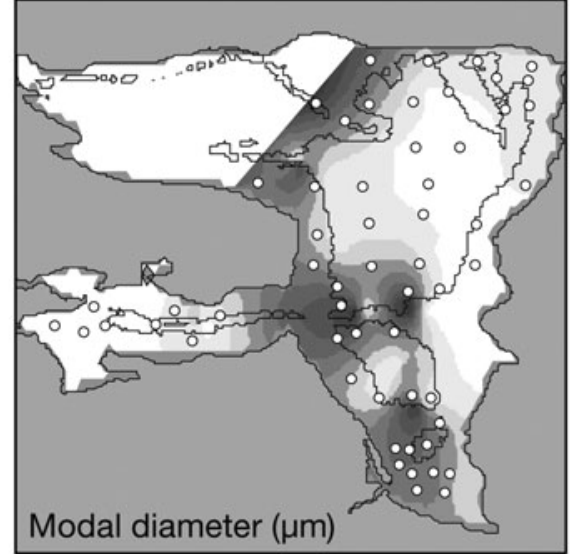

B
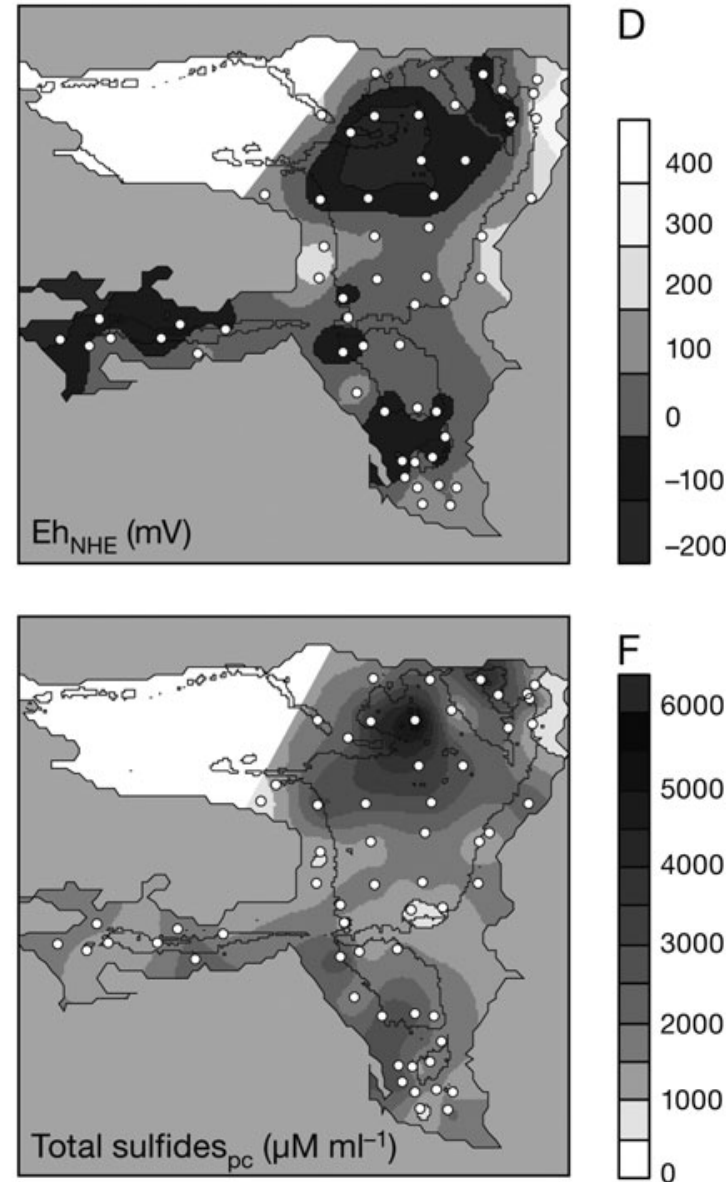

Fig. 2. Contour plots for depth and mean values for sediment variables measured in duplicate surface $(0-2 \mathrm{~cm})$ sediment samples from Tracadie Bay and Winter Harbour collected in July 2003. Open circles indicate sampling locations. (A) chart datum mean tide depth from Dowd (2003), (B) modal inorganic grain size, (C) organic matter, (D) $\mathrm{Eh}_{\mathrm{NHE}}$ (E) total free sulfides based on total sediment volume and $(\mathrm{F})$ total free sulfides based on sediment pore water volume

bined non-lease and Winter Harbour locations ( $t$-test, $\mathrm{p}=0.000)$. Although all regression curves shown in Fig. 3 were significant $(\mathrm{p}<0.05)$, low correlation coefficients $\left(r^{2}=0.22\right.$ to 0.57$)$ between some variables $(Z$, WC and S) contrasted higher values for WC and OM
(0.66 to 0.94). MANOVA results comparing log GS and dependent variables showed insignificant location effects for $Z$, WC or OM ( $p>0.125$ ) but significant ( $p=$ 0.000) effects for $E h_{\mathrm{NHE}}$ and $\mathrm{S}$ shown by separation of regression curves in Fig. 3D,E. 
Table 3. Results of 1-way MANOVA on surface $(0-2 \mathrm{~cm})$ sediment geochemical measurements at stations in Tracadie Bay sampled between July 9 and 17, 2003, for 7 dependent variables and 4 station categories described in Table 1. Eh $\mathrm{NHE}_{\mathrm{N}} \mathrm{Was}$ made positive $(+200 \mathrm{mV})$ and all variables were log-transformed before analysis. Hypotheses were tested by multivariate $F$-tests based on Pillai Trace statistics. Post-hoc multivariate comparisons between site categories and univariate $F$-tests for each response variable were performed for significant MANOVA results (bold: $\mathrm{p} \leq 0.05$ )

\begin{tabular}{|c|c|c|c|c|c|c|c|c|c|c|c|}
\hline \multirow[t]{2}{*}{ Hypothesis } & \multicolumn{4}{|c|}{ Multivariate test statistics } & \multicolumn{7}{|c|}{ Univariate $F$-test $\mathrm{p}$-values } \\
\hline & Pillai Trace & $F$-ratio & $\mathrm{df}$ & $\mathrm{p}$ & $Z$ & GS & WC & $\mathrm{OM}$ & $\mathrm{Eh}_{\mathrm{NHE}}$ & $\mathrm{S}$ & $\mathrm{S}_{\mathrm{pc}}$ \\
\hline $\mathrm{L}=\mathrm{NL}=\mathrm{NLZ}=\mathrm{WH}$ & H 1.296 & 5.432 & 21,150 & 0.000 & 0.000 & 0.000 & 0.000 & 0.000 & 0.000 & 0.000 & 0.000 \\
\hline $\mathrm{L}=\mathrm{NL}$ & 0.658 & 7.414 & 7,27 & 0.000 & 0.567 & 0.448 & 0.184 & 0.101 & 0.000 & 0.000 & 0.000 \\
\hline$L=N L Z$ & 0.816 & 19.664 & 7,31 & 0.000 & 0.001 & 0.000 & 0.000 & 0.000 & 0.000 & 0.000 & 0.000 \\
\hline $\mathrm{L}=\mathrm{WH}$ & 0.477 & 3.124 & 7,24 & 0.017 & 0.936 & 0.258 & 0.457 & 0.356 & 0.524 & 0.007 & 0.000 \\
\hline NL $=$ NLZ & 0.711 & 6.337 & 7,18 & 0.001 & 0.011 & 0.000 & 0.000 & 0.000 & 0.001 & 0.001 & 0.694 \\
\hline $\mathrm{NL}=\mathrm{WH}$ & 1.000 & 4.064 & 7,11 & 0.000 & 0.000 & 0.000 & 0.000 & 0.000 & 0.000 & 0.000 & 0.000 \\
\hline $\mathrm{NLZ}=\mathrm{WH}$ & 0.824 & 10.035 & 7,15 & 0.000 & 0.000 & 0.000 & 0.000 & 0.000 & 0.000 & 0.000 & 0.000 \\
\hline
\end{tabular}
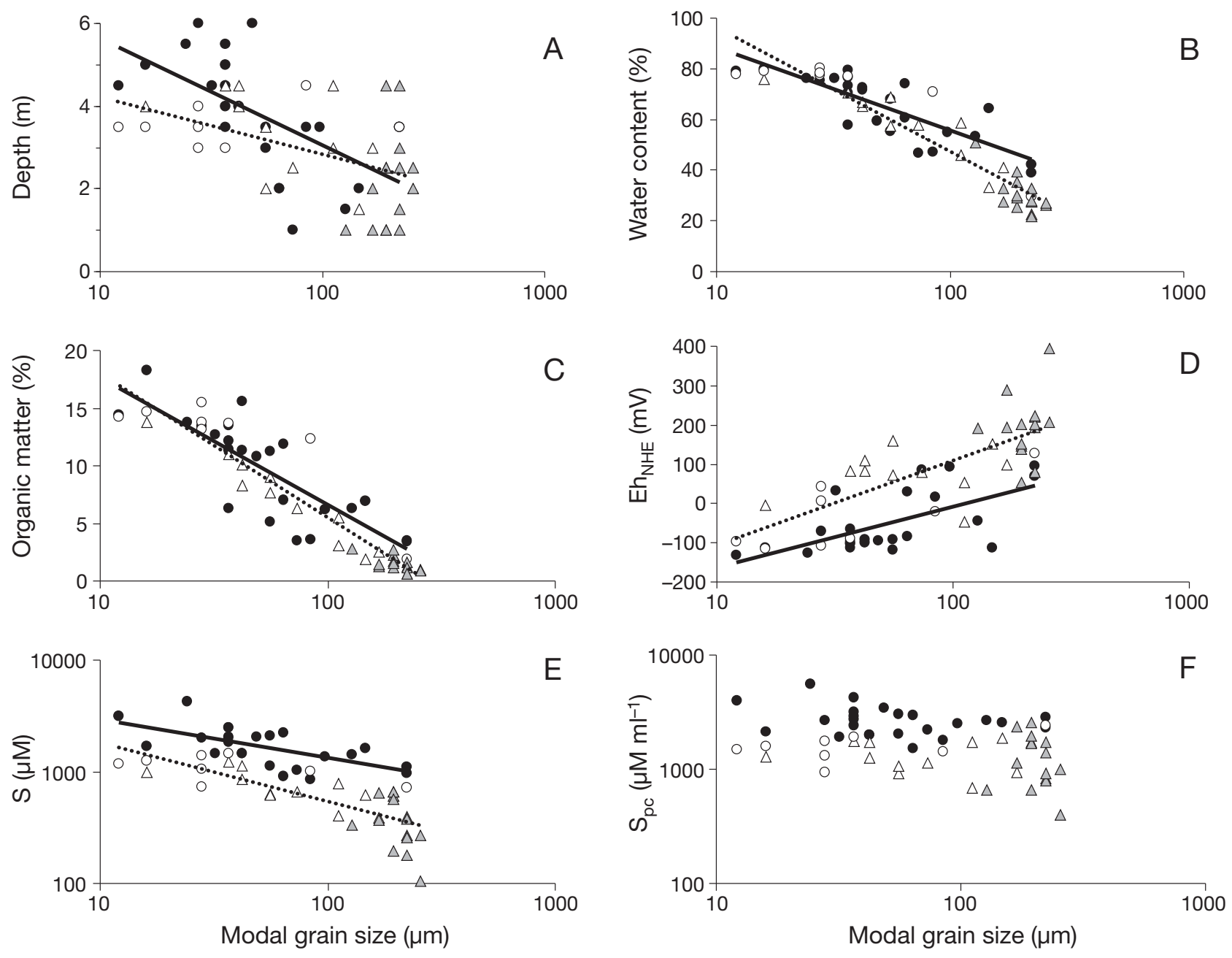

Fig. 3. Relationships between modal inorganic grain size and (A) depth, (B) water content, (C) organic matter, (D) Eh $\mathrm{NHE}_{\text {, and }}$ (E) total sulfides on sediment volume basis, $\mathrm{S}$, and $(\mathrm{F})$ total sulfides on pore water volume basis, $\mathrm{S}_{\mathrm{pc}}$, in surface $(0-2 \mathrm{~cm}) \mathrm{sedi}-$ ments within lease boundaries $(\bullet)$, non-lease sites ( $>25 \mathrm{~m}$ from leases) with $(\Delta)$ and without $(\Delta)$ Zostera, and in Winter Harbour (O). Solid lines: regression curves for data from mussel lease sites, dotted lines: non-lease sites with and without Zostera and Winter Harbour: (A) solid $y=8.2-1.19 \operatorname{Ln}(x), \mathrm{r}^{2}=0.35$; dotted $y=5.6-0.60 \operatorname{Ln}(x), \mathrm{r}^{2}=0.22 ;(B) \operatorname{solid} y=120.8-14.2 \operatorname{Ln}(x), \mathrm{r}^{2}=$ 0.67 ; dotted $y=144.9-21.2 \operatorname{Ln}(x), \mathrm{r}^{2}=0.89 ;(\mathrm{C})$ solid $y=28.7-4.80 \operatorname{Ln}(x), \mathrm{r}^{2}=0.66 ;$ dotted $y=30.4-5.40 \operatorname{Ln}(x), \mathrm{r}^{2}=0.91 ;(\mathrm{D})$ solid $y=-315.2+66.7 \operatorname{Ln}(x), r^{2}=0.40 ;$ dotted $y=-322.7+93.7 \operatorname{Ln}(x), r^{2}=0.56 ;(E)$ solid $y=6607 x^{-0.348}, r^{2}=0.41$; dotted $y=$ $5848 x^{-0.515}, r^{2}=0.57$. All regression lines shown are significant $(\mathrm{p}<0.05)$. Regression lines for lease and non-lease sites differed significantly for $\mathrm{Eh}_{\mathrm{NHE}}$ and $\mathrm{S}(\mathrm{MANOVA}, \mathrm{p}<0.05)$ 


\section{Organic enrichment classification}

$$
\text { K-means analysis }
$$

Since $E h_{\mathrm{NHE}}$ and measures of $\mathrm{S}$ were the 2 variables most different between lease and non-lease locations (Fig. 3D-F), K-means clustering was used to group stations based on $Z$-score transformed values of these variables (Table 4). The comparison of data includes results from previous observations of similar sediment geochemical variables in Tracadie Bay. WC was not reported by Wildish et al. (1999) or Miron et al. (2005), so $S_{p c}$ could not be calculated. K-means groups were therefore determined for comparison of data using $\mathrm{Eh}_{\mathrm{NHE}}$ and S. Better cluster discrimination was obtained using both variables than either one alone.

K-means groups (Table 4) corresponded to S concentrations characteristic of a previously described oxichypoxic-anoxic enrichment gradient (Wildish et al. 1999, 2001, Cranford et al. 2006, Hargrave et al. 2008). Two oxic $(<100$ to $\sim 1500 \mu \mathrm{M} \mathrm{S}$ with a separation at $\sim 750 \mu \mathrm{M} \mathrm{S})$ and 2 hypoxic enrichment categories ( $\sim 1500$ to $6000 \mu \mathrm{M} \mathrm{S}$, with a separation at $\sim 3000 \mu \mathrm{M} \mathrm{S})$ were identified. The corresponding ranges of $\mathrm{Eh}_{\mathrm{NHE}}$ for the station groups were Oxic A: >+100; Oxic B: +100 to -50 ; Hypoxic A: -50 to -100 ; Hypoxic B: -100 to -150 : Anoxic: $<-150 \mathrm{mV}$. The number of observations in Winter Harbour was small $(\mathrm{n}=8)$ and samples were assigned to a single cluster (Oxic B).

$$
\mathrm{Eh}_{\mathrm{NHE}}-\mathrm{S} \text { relationships }
$$

The inverse correlation between $\mathrm{Eh}_{\mathrm{NHE}}$ and $\mathrm{S}$ shows that $\mathrm{S}$ was generally $>1000 \mu \mathrm{M}$ and that $\mathrm{Eh}_{\mathrm{NHE}}$ was $<+100 \mathrm{mV}$ in sediments from mussel leases (Fig. 4A). Non-lease sites with Zostera (maximum $655 \mu \mathrm{M} \mathrm{S}$, Table 1) were less than the threshold $(750 \mu \mathrm{MS})$ separating Oxic A and B enrichment classes (Table 4). The corresponding $E h_{\mathrm{NHE}}$ threshold was $>+100 \mathrm{mV}$. Since with one exception, $E h_{\mathrm{NHE}}$ was always positive for this sediment category (Table 1), $\mathrm{BEI}_{\mathrm{OM}}$ derived as a product of

Table 4. Ranges (min.-max.) of total sulfides (S) ( $\mu \mathrm{M}$ [sediment volume] ${ }^{-1}$ ); parentheses: $\mathrm{n}$ in each data group based on K-means clustering of $Z$-score standardized values of $E h_{\mathrm{NHE}}$ and $\mathrm{S}$ in surface $(0-2 \mathrm{~cm})$ sediments from Tracadie Bay. ' 0 ' indicates no observations in an enrichment class. Data clusters are identified using terminology based on ranges of $\mathrm{S}$ concentrations defined in Wildish et al. (2001) and Cranford et al. (2006). Site types designated as mussel Mytilus edulis lease (L) and non-lease (NL) locations $>25 \mathrm{~m}$ from lease boundaries. Non-culture inlets (NC) did not have mussel aquaculture at the time of sampling. Only spat

\begin{tabular}{|c|c|c|c|c|c|c|c|}
\hline \multirow{2}{*}{$\begin{array}{l}\text { Year } \\
(\mathrm{mo})\end{array}$} & \multirow[t]{2}{*}{ Site type } & \multicolumn{5}{|c|}{ - Sediment organic enrichment class } & \multirow{2}{*}{ Source } \\
\hline & & $\begin{array}{c}\text { Oxic A } \\
(0-750 \mu \mathrm{M})\end{array}$ & $\begin{array}{c}\text { Oxic B } \\
(750-1500 \mu \mathrm{M})\end{array}$ & $\begin{array}{c}\text { Hypoxic A } \\
(1500-3000 \mu \mathrm{M})(\end{array}$ & $\begin{array}{c}\text { Hypoxic B } \\
(3000-6000 \mu \mathrm{M})\end{array}$ & $\begin{array}{c}\text { Anoxic } \\
(>6000 \mu \mathrm{M})\end{array}$ & \\
\hline \multirow{3}{*}{$\begin{array}{l}1997 \\
\text { (Aug/Sep) }\end{array}$} & $\mathrm{L}$ & $360-774(6)$ & $287-1485(23)$ & $1572-2643(8)$ & $4188(1)$ & 0 & \multirow[t]{3}{*}{ Shaw $(1998)^{\mathrm{a}}$} \\
\hline & NL & $227-694$ (15) & 526-1660 (16) & $1801-3343(6)$ & 0 & 0 & \\
\hline & $\mathrm{NC}$ & $115-976(13)$ & $233-1457(24)$ & $2154-2857(8)$ & 0 & 0 & \\
\hline \multirow{2}{*}{$\begin{array}{l}1998 \\
\text { (Aug) }\end{array}$} & $\mathrm{L}$ & 0 & $63-1400(21)$ & $1200-2900(11)$ & $5700(1)$ & 0 & \multirow{2}{*}{$\begin{array}{l}\text { Wildish et al. } \\
(1999)^{b}\end{array}$} \\
\hline & NL & $18-640(6)$ & $150-1900(13)$ & 0 & $3500-4500(2)$ & 0 & \\
\hline \multirow{3}{*}{$\begin{array}{l}2000 \\
\text { (Nov) }\end{array}$} & $\mathrm{L}$ & 0 & $389-1140(6)$ & 0 & $3610-5550(3)$ & $6490-9230(6)$ & \multirow{3}{*}{$\begin{array}{l}\text { Miron et al. } \\
(2005)^{\mathrm{c}}\end{array}$} \\
\hline & NL & 0 & 980,1118 & 0 & 0 & 0 & \\
\hline & WH & 0 & 0 & 0 & 0 & 6010,6203 & \\
\hline \multirow{3}{*}{$\begin{array}{l}2003 \\
\text { (Jul) }\end{array}$} & $\mathrm{L}$ & 0 & $855-1470(7)$ & $1120-2500(15)$ & $3140-4220(2)$ & 0 & \multirow[t]{3}{*}{ Present study ${ }^{\mathrm{d}}$} \\
\hline & $\mathrm{NL}^{\mathrm{e}}$ & $104-390(9)$ & $270-1230(17)$ & 0 & 0 & 0 & \\
\hline & WH & 0 & $713-1460(8)$ & 0 & 0 & 0 & \\
\hline \multirow{3}{*}{$\begin{array}{l}2003 \\
\text { (Jul) }\end{array}$} & $\mathrm{L}$ & 0 & 0 & $1508-2845$ (13) & $2953-5542(11)$ & 0 & \multirow[t]{3}{*}{ Present study ${ }^{\mathrm{f}}$} \\
\hline & $\mathrm{NL}^{\mathrm{e}}$ & 0 & 395-1138 (8) & $690-2554$ (18) & 0 & 0 & \\
\hline & WH & 0 & 938-1899 (8) & 0 & 0 & 0 & \\
\hline \multicolumn{8}{|c|}{$\begin{array}{l}{ }^{\text {a }} \text { Combined results from } 0-4 \mathrm{~cm} \text { surface sediments at stations located in } 19 \text { inlets in PEI with (10) and without (9) mussel } \\
\text { aquaculture including samples from Tracadie Bay ( } \mathrm{n}=7 \text { stations) } \\
\text { bS concentrations reported in Wildish et al.'s (1999) Appendix } 2 \text { were divided by } 10 \text { to correct for a presumed calibration } \\
{ }^{\mathrm{c}} \text { Alkaline conditions created by storage of sediment samples with sulfide antioxidant buffer solution (SAOB) solution cou }\end{array}$} \\
\hline
\end{tabular}
collection occurs in Winter Harbour (WH) in Tracadie Bay 

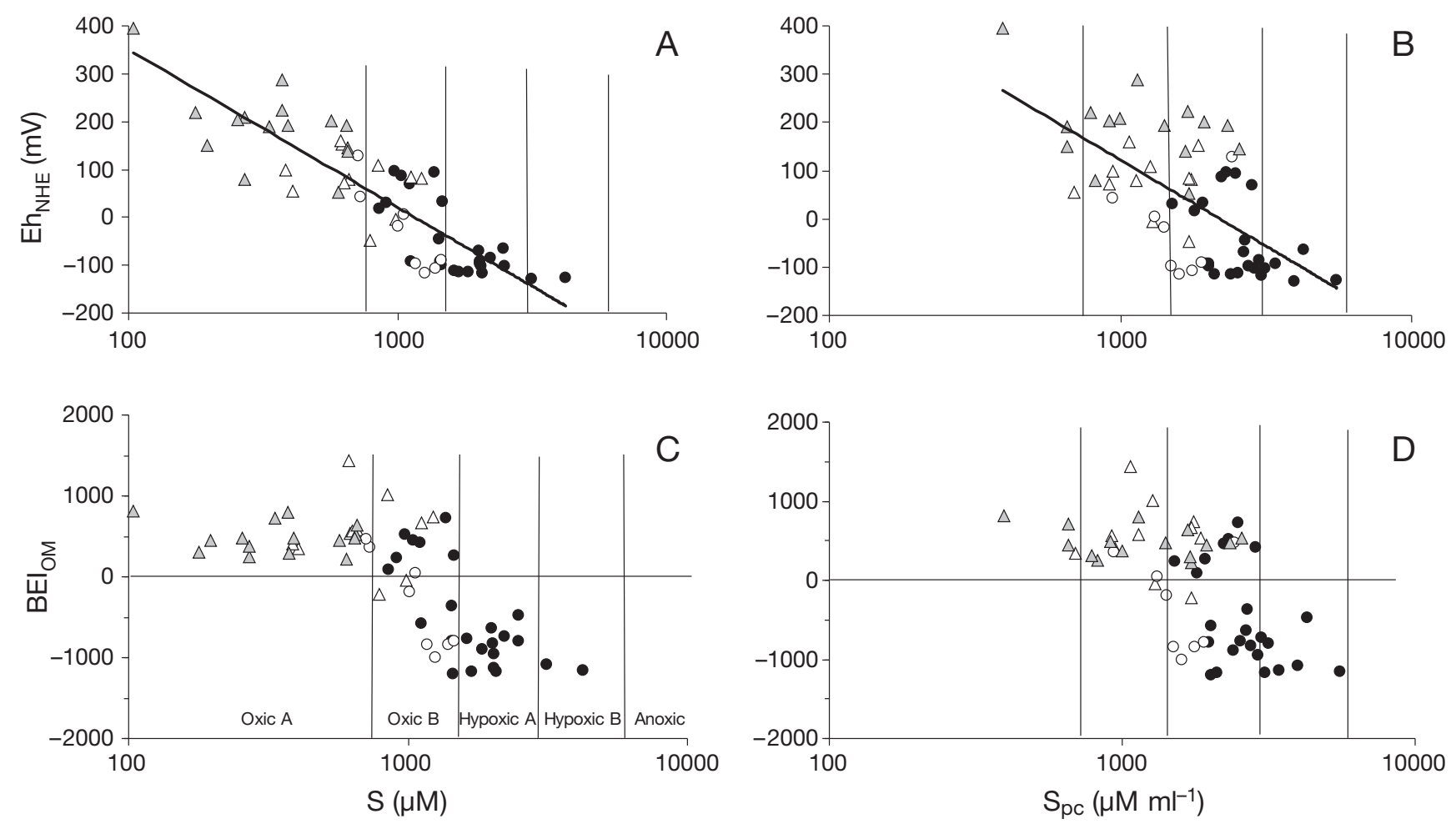

Fig. 4. Relationships between $\mathrm{Eh}_{\mathrm{NHE}}$ and a Benthic Enrichment Index (BEI $\mathrm{OM}$ ) and total sulfides on the basis of sediment volume $(\mathrm{S})$ (panels $A$ and $C$ ) and pore water volume $\left(S_{p c}\right)$ (panels B and D) in surface $(0-2 \mathrm{~cm}$ ) sediment from Tracadie Bay in July 2003. Data from lease sites $(\bullet)$, non-lease areas with $(\Delta)$ and without $(\Delta)$ Zostera, and Winter Harbour $(0)$. Regression lines for all data: (A) $y=1009.3-143.1 \operatorname{Ln}(x), r^{2}=0.74, p<0.05$; (B) $y=1195-155.2 \operatorname{Ln}(x), r^{2}=0.40, p<0.05$. Vertical lines indicate mean threshold values for 5 sediment organic enrichment categories labeled in panel $\mathrm{C}$ based on $\mathrm{S}$ shown in Table 5 and described in Hargrave et al. (2008). S ( $\mu \mathrm{M})$ concentration thresholds in each enrichment category: Oxic A: 750, Oxic B: 1500, Hypoxic A: 3000, Hypoxic B: 6000, Anoxic: > 6000

$\mathrm{Eh}_{\mathrm{NHE}}$ (Eq. 3) was always positive (Fig. 4C). Non-lease areas without Zostera and all stations in Winter Harbour showed intermediate levels of organic enrichment $\left(\mathrm{S}=750\right.$ to $1500 \mu \mathrm{M}, \mathrm{Eh}_{\mathrm{NHE}}=+100$ to $-50 \mathrm{mV}, \mathrm{BEI}_{\mathrm{OM}}=$ +1000 to -1000 ) characteristic of Oxic B type sediments. Eleven lease locations were classified as Oxic B and 13 had negative $\mathrm{BEI}_{\mathrm{OM}}$ values characteristic of Hypoxic $\mathrm{A}$ and $\mathrm{B}$, categories associated with $\mathrm{S}>1500 \mu \mathrm{M}$ and negative $\mathrm{Eh}_{\mathrm{NHE}}(<-50 \mathrm{mV})$ (Fig. 4A,C).

$\mathrm{K}$-means groupings based on $\mathrm{Eh}_{\mathrm{NHE}}$ and $\mathrm{S}_{\mathrm{pc}}$ produced station clusters similar to enrichment classes described by $\mathrm{Eh}_{\mathrm{NHE}}$ and S (Fig. 4B). Approximately equal numbers of lease stations were classified in the Hypoxic A and B categories and non-lease locations were less enriched (Oxic B and Hypoxic A categories). Data clusters from Winter Harbour based on $\mathrm{S}_{\mathrm{pc}}$ appeared as a single group (Oxic B), similar to the classification based on S. Relationships between $\mathrm{Eh}_{\mathrm{NHE}}, \mathrm{BEI}_{\mathrm{OM}}$ and $\mathrm{S}_{\mathrm{pc}}$ resembled those for $\mathrm{S}$, but data was shifted to the right (Fig. 4B,D). As in Fig. 4A,C, with $\mathrm{S}$ as the independent variable, the plots for $\mathrm{S}_{\mathrm{pc}}$ show a general separation of non-lease (generally positive $\mathrm{Eh}_{\mathrm{NHE}}$ and $\mathrm{BEI}_{\mathrm{OM}}$ values) and lease (more negative $\mathrm{Eh}_{\mathrm{NHE}}$ and $\mathrm{BEI}_{\mathrm{OM}}$ values) locations.

\section{Multi-dimensional scaling}

MDS analysis included all measured variables to separate lease, non-lease and Winter Harbour locations (Fig. 5). Non-lease sites with and without Zostera, clustered to the right in both plots, were also separated in the multivariate space. Stress values for both analyses using $S$ and $S_{p c}$ were low $(<0.008)$, indicating a good fit with minimum discrepancies between inter-point distances and the smoothed distances predicted from dissimilarities. Pearson rank correlations showed that Dimension 1 (DIM 1) was directly correlated with S and $\mathrm{S}_{\mathrm{pc}}$, while DIM 2 was correlated with all other variables (Table 5). Coefficients for GS, WC, OM and $\mathrm{Eh}_{\mathrm{NHE}}$ with DIM 2 were similar with higher values for $\mathrm{S}_{\mathrm{pc}}$ than for $\mathrm{S}$.

The location of enrichment zones along the DIM 1 axis of the MDS plot, defined by ranges of $\mathrm{S}$ indicated in Table 4, were determined using correlations between DIM 1 and $\mathrm{S}$ and $\mathrm{S}_{\mathrm{pc}}$ (Table 5). Based on $\mathrm{S}$ concentrations, lease locations clustered in Oxic B, Hypoxic A and B enrichment categories, while nonlease sites were classified as Oxic A and B (Fig. 5A). Winter Harbour sites were all primarily in the Oxic B 


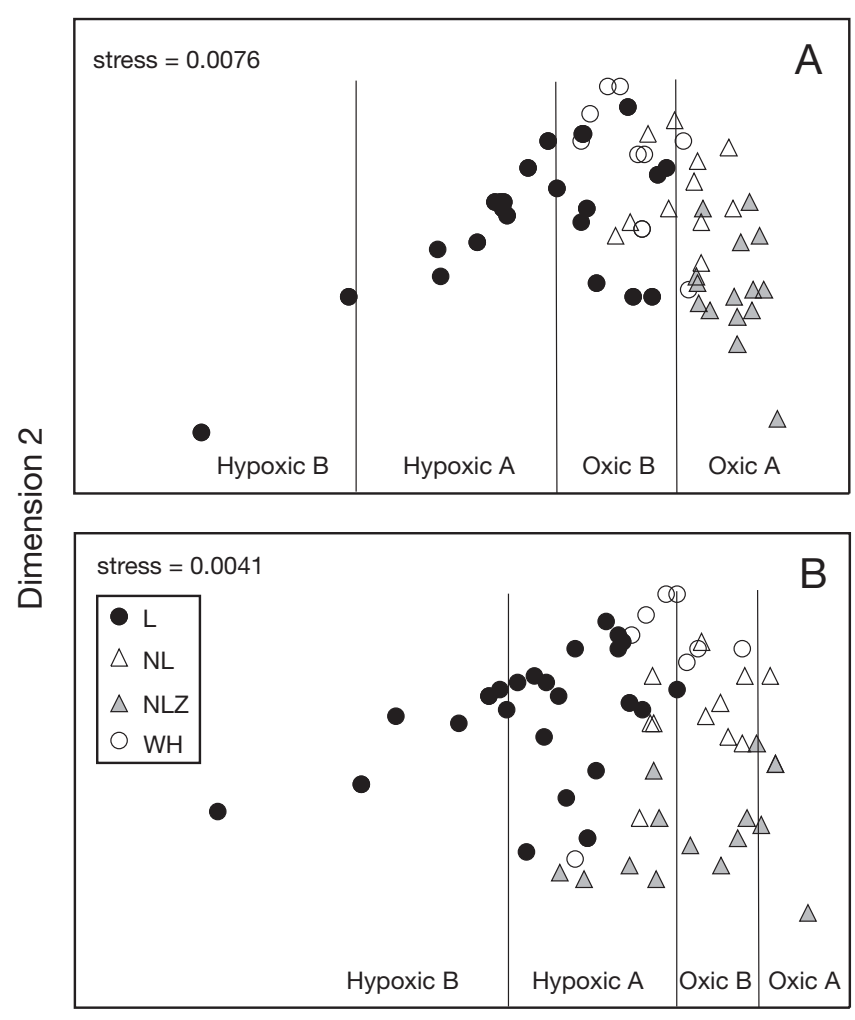

Dimension 1

Fig. 5. Multi-dimensional scaling (MDS) plots based on variables measured in surface ( $0-2 \mathrm{~cm}$ layer) sediment in Tracadie Bay in July 2003 described in Tables 3 \& 4. (A) total sulfides (S) as $\mu \mathrm{M}$ [volume of sediment] ${ }^{-1}$. (B) total sulfides based on sediment pore water volume $\left(\mathrm{S}_{\mathrm{pc}}\right)$ as $\mu \mathrm{M} \mathrm{ml}^{-1}$ pore water volume. Symbols indicate station categories: $(\bullet)$ mussel leases $(L),(\Delta, \Delta)$ non-lease sites without (NL) and with (NLZ) Zostera, respectively; (O) Winter Harbour (WH). Both plots represent the same multivariate space defined by a single MDS analysis. Vertical lines: separation between organic enrichment categories shown in Fig. 4 and the correlation between $\mathrm{S}$ and MDS Dimension 1 (Table 5)

Table 5. Pearson correlation coefficients (r) between variables described in Table 1 for samples collected in Tracadie Bay during July 2003 ( $\mathrm{n}=58)$ and 2 dimensions from MDS analysis (Fig. 5). Bold values indicate variables most highly correlated $(\mathrm{p}<0.05)$ with each dimension

\begin{tabular}{|c|c|c|c|c|c|c|}
\hline Variable & GS & WC & OM & $E h_{\mathrm{NHE}}$ & S & DIM 1 \\
\hline WC & -0.930 & & & & & \\
\hline $\mathrm{OM}$ & -0.881 & 0.957 & & & & \\
\hline$E h_{\text {NHE }}$ & 0.756 & -0.806 & -0.779 & & & \\
\hline $\mathrm{S}$ & -0.640 & 0.667 & 0.669 & -0.772 & & \\
\hline DIM 1 & 0.649 & -0.677 & -0.677 & 0.781 & -1.000 & \\
\hline DIM 2 & -0.583 & 0.579 & 0.520 & -0.596 & -0.012 & -0.004 \\
\hline Variable & GS & WC & OM & $E h_{\mathrm{NHE}}$ & $\mathrm{S}_{\mathrm{pc}}$ & DIM 1 \\
\hline $\mathrm{S}_{\mathrm{pc}}$ & -0.343 & 0.322 & 0.341 & -0.583 & & \\
\hline DIM 1 & 0.351 & -0.330 & -0.348 & 0.591 & -1.000 & \\
\hline DIM 2 & -0.821 & 0.849 & 0.795 & -0.781 & -0.014 & 0.004 \\
\hline
\end{tabular}

category. Corresponding classifications based on $\mathrm{S}_{\mathrm{pc}}$ showed enrichment zones shifted to the right (Fig. 5B). Lease and non-lease locations were separated with lease sites in the Hypoxic A and B categories and other locations representing Oxic A to Hypoxic A enrichment zones.

\section{DISCUSSION}

\section{Bathymetric and regional effects of organic enrichment}

Our observations show that lease-scale effects of benthic organic enrichment from mussel aquaculture must be assessed recognizing that inlet-wide variations occur in sediment geochemical variables due to physical and bathymetric factors. For example, significant inverse correlations between GS and $\mathrm{WC}, \mathrm{OM}, \mathrm{S}, \mathrm{S}_{\mathrm{pc}}$ and positive correlations with $\mathrm{Eh}_{\mathrm{NHE}}$ accounted for general inlet-wide distributional patterns of these geochemical variables (Fig. 2), while fine-grained, organic-materialrich sediments predominated in deeper $(>5 \mathrm{~m})$ areas of the inlet (Fig. 3). Resuspension and erosion at shallow depths and transport of feces and pseudofeces produced by mussels to deeper water would explain lower $\mathrm{OM}, \mathrm{S}$ and $\mathrm{S}_{\mathrm{pc}}$ and more positive $\mathrm{Eh}_{\mathrm{NHE}}$ in shallow regions of the bay. High OM and negative $\mathrm{Eh}_{\mathrm{NHE}}$ in Winter Harbour imply that river input is a major source of $\mathrm{OM}$. We would expect terrigenous OM to be more refractory to decomposition than mussel biodeposits, which could explain why OM was increased and $\mathrm{Eh}_{\mathrm{NHE}}$ was negative in Winter Harbour but maximum concentrations of $\mathrm{S}$ were not as high as in Tracadie Bay.

Spatial differences in sediment geochemical variables reflect interactions between tidal transport of suspended particles, sedimentation rates and mussel feeding activity. Dowd (2003) modeled seston dynamics in Tracadie Bay to show that biological factors (grazing and primary production) influenced concentrations and flux near the head of the bay, while seston dynamics were more physically controlled by tidal advection near the mouth. Grant et al. (2005) used sediment traps to show that daily fluxes under mussel lines were double those at non-lease sites. OM and chloropigments sedimented under mussel lines were also different, as would be expected if mussel feeding influenced deposited material. Remotesensing observations and a spatially explicit model of seston physical transport and removal through mussel feed- 
ing activity have also confirmed that particle depletion due to mussel feeding is a major factor controlling seston levels in Tracadie Bay (Grant et al. 2007a,b).

Regional or inlet-wide effects of benthic enrichment due to mussel feeding might also be expected in Tracadie Bay based on a nitrogen budget model (Cranford et al. 2007). Results showed that mussel food supplies could be depleted and nitrogen burial in sediments increased by up to an order of magnitude in box model Region 1, where mussel culture is most intense (Fig. 1). However, MANOVA results of logtransformed values of variables with data grouped by model area showed no significant differences for OM $(p=0.069)$ or any other variable $(p>0.03)$ between the 3 box model regions. This could reflect the fact that stations from a range of depths and GS were combined in model regions increasing variability in the data.

\section{Lease-scale effects}

In addition to the role of physical factors in controlling levels of organic enrichment in sediments, local or lease-scale effects of mussel culture have been observed. Several previous studies in relatively shallow areas with generally low tidal currents have shown that benthic enrichment effects similar to those we observed (increased WC, OM and S, and decreased $\mathrm{Eh}_{\mathrm{NHE}}$ ) were localized within or close to lease boundaries (Hatcher et al. 1994, Grant et al. 1995, Chamberlain et al. 2001, Hartstein \& Rowden 2004, Callier et al. 2006, Metzger et al. 2007). However, other studies have not found similar relationships (Crawford et al. 2003, Anderson et al. 2005, Miron et al. 2005). The discrepancy between studies may be due to undersampling where station numbers were too low to detect spatial patterns. It could also reflect effects of higher current velocities and greater water depth moderating fluxes of biodeposits to the seabed. Deep water could decrease potential negative effects of benthic enrichment due to dispersion of mussel biodeposits. $E h_{\mathrm{NHE}}$ and $\mathrm{S}$ measurements around mussel leases in cold, deep water in Newfoundland showed that most sediments were oxic (Anderson et al. 2005). In contrast, $\mathrm{S}$ and $\mathrm{S}_{\mathrm{pc}}$ were higher, $\mathrm{Eh}_{\mathrm{NHE}}$ lower and $\mathrm{BEI}_{\mathrm{OM}}$ values more negative in lease vs. non-lease areas in Tracadie Bay (Fig. 4).

Algal and bacterial biofilms observed in central areas of Tracadie Bay, where mussel culture intensity is greatest, provide additional evidence for benthic organic enrichment (Cranford et al. 2006). Video images showed that Beggiatoa mats were most extensive (50 to $80 \%$ cover of $1 \mathrm{~m}^{2}$ video images) within leases in deeper regions of the bay where $\mathrm{S}$ and $\mathrm{S}_{\mathrm{pc}}$ were generally $>1000$ and $2000 \mu \mathrm{M}$, respectively
(Fig. 2E,F). Bacterial mats, which also occurred in Winter Harbour, but with a more patchy distribution, have often been used as an indicator of excessive organic matter loading associated with finfish aquaculture (Brooks \& Mahnken 2003). Previous studies have also reported the occurrence of bacterial and algal mats under mussel lines (Hatcher et al. 1994, Grant et al. 1995) but areal coverage was much less than we observed within mussel leases.

As in our study, significant differences in sediment geochemical variables between mussel lease and nonlease sampling stations were observed by Shaw (1998) in Tracadie Bay and several other PEI inlets where mussel aquaculture was carried out. In contrast, Miron et al. (2005) measured the same variables but concluded that benthic conditions in Tracadie Bay were homogeneous and effects of mussel culture on benthic enrichment could not be demonstrated. This conclusion may reflect the fact that 17 of 19 stations sampled in that study were within lease boundaries (Fig. 1). Sedimentary characteristics were consistent with distributional patterns for similar variables in our study, with fine-grained deposits, high OM and $\mathrm{S}$ and lower $\mathrm{Eh}_{\mathrm{NHE}}$ in deep water areas. OM values reported for the 2 non-lease stations in Miron et al. (2005) are similar to values for coarse-grained sediments that we observed in non-lease locations with Zostera. Higher $\mathrm{Eh}_{\mathrm{NHE}}$ and lower $\mathrm{S}$ and $\mathrm{S}_{\mathrm{pc}}$ concentrations reflect oxic conditions that could be maintained by oxidation of $\mathrm{S}$ within the eelgrass rhizosphere (Pedersen et al. 2004).

\section{Sediment organic enrichment classification based on Eh-S relationships}

The sensitivity of $\mathrm{Eh}_{\mathrm{NHE}}$ and $\mathrm{S}$ for indicating enrichment within mussel leases was shown by regressions of these variables on GS (Fig. 3D,E), while the separation of oxic and hypoxic enrichment classes of sediment was based on relationships between $E h_{\mathrm{NHE}}, \mathrm{S}$ and $\mathrm{S}_{\mathrm{pc}}$ (Fig. 4). The separation of lease and non-lease locations in multivariate space (Fig. 5) explains why K-means clustering using $\mathrm{Eh}_{\mathrm{NHE}}$ with either $\mathrm{S}$ or $\mathrm{S}_{\mathrm{pc}}$ was more effective for enrichment class identification (Table 4) than groupings based on only 1 of the variables. It also accounts for the spatial separation of stations using MDS since Dimension 1 was directly correlated with S (Table 5).

Although intercept and slope parameters for regressions between WC and OM and GS for lease and non-lease locations were not significantly different, non-lease sites with Zostera, characterized by more coarse-grained oxic sediments, were clustered below the regression line for leases (Figs. 3B,C). The results show that although differences in grain size strongly 
influence broad spatial patterns in the distribution of sediment geochemical variables in the bay, organic enrichment effects at the lease- scale are clearly indicated by differences in $\mathrm{S}$ and $\mathrm{Eh}_{\mathrm{NHE}}$.

The oxic-hypoxic-anoxic terminology describing organic enrichment gradients as proposed by Wildish et al. (2001) is not intended to imply that oxygen and S co-exist in surface sediments. Oxygen supplied by diffusion and advective processes is rapidly consumed by aerobic respiration and non-biological chemical oxidation of $\mathrm{S}$ in surface layers. Zostera may prevent $\mathrm{S}$ accumulation within the rhizome due to oxygen released from roots (Pedersen et al. 2004), but even in these areas dissolved $\mathrm{H}_{2} \mathrm{~S}_{1} \mathrm{HS}^{-}$and $\mathrm{S}^{2-}$, and reduced particulate compounds such as $\mathrm{FeS}$ and pyrite formed by sulfate reduction are oxidized by oxygen (Leon et al. 2004, Jézéquel et al. 2007). With increasing organic matter input sulfate reduction in subsurface layers will be stimulated (Dahlbäck \& Gunnarsson 1981) and since vertical oxygen supply is limited, reduced S compounds will accumulate closer to the sediment surface. Sediment profile imaging has shown that hypoxic conditions in surface sediments are characterized by reduced oxygen penetration and lower $\mathrm{Eh}_{\mathrm{NHE}}$ near the sediment surface (Nilsson \& Rosenberg 2000).

The ranges of $\mathrm{Eh}_{\mathrm{NHE}}$ for oxic and hypoxic categories identified using K-means clustering (Table 4) are similar to those used for classification of salmon aquaculture sites in Norway (Schaanning \& Kupka Hansen 2005) and the southwestern Bay of Fundy, Canada (Wildish et al. 2001). BEI $\mathrm{OM}_{\mathrm{OM}}$ values in mussel leases and in Winter Harbour (Fig. 4C,D) are similar to ranges of positive values of the BEI index based on organic carbon rather than on OM (Eq. 3) measured in surface sediments away from salmon net pens. Negative values in organically rich sediments under salmon cages in the southwestern Bay of Fundy (Hargrave et al. 1997) are similar to those in mussel lease areas in Tracadie Bay in 1997 (Shaw 1998) and in our study (Fig. 4).

$\mathrm{K}$-means clustering indicated separation of sediment types into 5 enrichment groups (Table 4) rather than the 3 (oxic, hypoxic and anoxic) proposed by Wildish et al. (2001). The hypoxic category ( 1500 to $6000 \mu \mathrm{M} \mathrm{S}$ and $<-50 \mathrm{mV}$ ) was separated at $\sim 3000 \mu \mathrm{M} \mathrm{S}$ and $\mathrm{Eh}_{\mathrm{NHE}}$ of $-100 \mathrm{mV}$. The transition represents a threshold within the broad hypoxic range similar to the range of S identified by Brooks \& Mahnken (2003) associated with changes in the relative abundance of nonopportunistic and opportunistic benthic macrofauna. The total number of non-opportunistic species was reduced by $\sim 70 \%$ of the mean at $\sim 3000 \mu \mathrm{M} \mathrm{S}$. Further studies are required to confirm large changes in benthic faunal community composition, which appear to occur as organic enrichment causes a transition from Hypoxic A to Hypoxic B type sediments.
Our study has shown that spatial differences between lease and non-lease locations in Tracadie Bay, a shallow coastal inlet with intensive mussel aquaculture, can be detected using measures of $\mathrm{Eh}_{\mathrm{NHE}}$ and $\mathrm{S}$ in surface (upper $2 \mathrm{~cm}$ ) sediments. Inverse relationships between S and GS and positive regressions between $\mathrm{Eh}_{\mathrm{NHE}}$ and GS at lease and non-lease locations showed that $\mathrm{S}$ and $\mathrm{Eh}_{\mathrm{NHE}}$ were more sensitive than WC or OM in differentiating lease from non-lease sites. Clustering methods also showed that geochemical variables can be used to group stations into benthic organic enrichment categories similar to those observed at finfish aquaculture sites, as well as in previous studies in Tracadie Bay. Mussel leases were characterized by hypoxic sediments as opposed to more oxic deposits at non-lease sites and differences between the location categories were quantified by $\mathrm{S}$ and $\mathrm{Eh}_{\mathrm{NHE}}$.

Acknowlegements. We thank G. A. Phillips for assistance in the laboratory and J. N. Smith, and T. Sephton for comments on the manuscript. This work was funded by Fisheries and Oceans Canada through the ESSRF program.

\section{LITERATURE CITED}

Anderson MR, Tlusty MF, Pepper VA (2005) Organic enrichment at cold water aquaculture sites-the case of coastal Newfoundland. In Hargrave BT (ed) Environmental effects of marine finfish aquaculture. Handbook Environ Chem 5, Springer, Berlin, p 99-113

Brooks KM, Mahnken CVM (2003) Interactions of Atlantic salmon in the Pacific northwest environment. II. Organic wastes. Fish Res 62:255-293

Callier MD, Weise AM, McKindsey CW, Desrosiers G (2006) Sedimentation rates in a suspended mussel farm (GreatEntry Lagoon, Canada): biodeposit production and dispersion. Mar Ecol Prog Ser 322:129-141

Chamberlain J, Fernandes TF, Read P, Nickell TD, Davies IM (2001) Impacts of deposits from suspended mussel (Mytilus edulis L.) culture on the surrounding surficial sediments. ICES J Mar Sci 58:411-416

Cranford PJ, Anderson R, Archambault P, Balch T and others (2006) Indicators and thresholds for use in assessing shellfish aquaculture impacts on fish habitat. DFO Can Sci Advis Sec Res Doc 2006/034 Can Dept Fish, Oceans, Ottawa

Cranford PJ, Strain PM, Dowd M, Hargrave BT, Grant J, Archambault MC (2007) Influence of mussel aquaculture on nitrogen dynamics in a nutrient enriched coastal embayment. Mar Ecol Prog Ser 347:61-78

Crawford CM, Macleod CKA, Mitchell IM (2003) Effects of shellfish farming on the benthic environment. Aquaculture 224:117-140

Dahlbäck B, Gunnarsson LAH (1981) Sedimentation and sulfate reduction under a mussel culture. Mar Biol 63: 269-275

> Dame RF, Prins TC (1997) Bivalve carrying capacity in coastal ecosystems. Aquat Ecol 31:409-421

> Dowd M (2003) Seston dynamics in a tidal inlet with shellfish aquaculture: a model study using tracer equations. Estuar Coast Shelf Sci 57:523-537

Dowd M (2005) A biophysical model for assessing environ- 
mental effects of marine bivalve aquaculture. Ecol Model 183:323-346

Dowd M, Page FH, Losier R, McCurdy P, Bugden G (2001) Physical oceanography of Tracadie Bay, PEI: analysis of sea level, current, wind and drifter data. Can Tech Rep Fish Aquat Sci 2347

Grant J, Hatcher A, Scott DB, Pocklington P, Schafer CT, Winter G (1995) A multidisciplinary approach to evaluating benthic impacts of shellfish aquaculture. Estuaries 18: $124-144$

Grant J, Cranford PJ, Hargrave B, Carreau M and others (2005) A model of aquaculture biodeposition for multiple estuaries and field validation at blue mussel (Mytilus edulis) culture sites in eastern Canada. Can J Fish Aquat Sci 62:1271-1285

Grant J, Bugden G, Horne E, Archambault MC, Carreau M (2007a) Remote sensing of particle depletion by coastal suspension-feeders. Can J Fish Aquat Sci 64:387-390

Grant J, Bacher C, Cranford PJ, Guyondet T, Carreau M (2007b) A spatially explicit ecosystem model of seston depletion in dense mussel culture. J Mar Syst. doi:10.1016/ jmarsyst.2007.10.007

Gregory D, Petrie B, Jordan F, Langille P (1993) Oceanographic, geographic, and hydrological parameters of Scotia-Fundy and southern Gulf of St. Lawrence inlets. Can Tech Rep Hydrogr Ocean Sciences 143:1-248

Hargrave BT (1994) A benthic enrichment index. In: Hargrave BT (ed) Modelling benthic impacts of organic enrichment from marine aquaculture. Can Tech Rep Fish Aquat Sci 1949, p 79-91

Hargrave BT, Phillips GA, Doucette LI, White MJ, Milligan TG, Wildish DJ, Cranston RE (1997) Assessing benthic impacts of organic enrichment from marine aquaculture. Water Air Soil Pollut 99:641-650

Hargrave BT, Holmer M, Newcombe CP (2008) Towards a classification of organic enrichment in marine sediments based on biogeochemical indicators. Mar Pollut Bull 56:810-824

Hartstein ND, Rowden AA (2004) Effect of biodeposits from mussel culture on macroinvertebrate assemblages at sites of different hydrodynamic regime. Mar Environ Res 57: 339-357

Hatcher A, Grant J, Schofield B (1994) Effects of suspended mussel culture (Mytilus spp.) on sedimentation, benthic respiration and sediment nutrient dynamics in a coastal bay. Mar Ecol Prog Ser 115:219-235

Jézéquel D, Brayner R, Metzger E, Viollier E, Prévot F, Flévet F (2007) Two-dimensional determination of dissolved sulfur species in marine sediment pore-water by thin-film based imaging. Thau lagoon (France). Estuar Coast Shelf Sci 72:420-431

Kranck K, Milligan TG (1979) The use of Coulter Counters in studies of particle size distributions in aquatic environments. Bedford Institute of Oceanography, Dartmouth, Nova Scotia, Report Series/BI-R-79-7

Editorial responsibility: Matthias Seaman, Oldendorf/Luhe, Germany
Leon I, Mendez G, Rubio B (2004) Geochemical phases of Fe and degree of pyritization in sediments from Ria de Pontevedra (NW Spain): Implications of mussel raft culture. Cienc Mar 30:585-602

> Metzger E, Simonucci C, Viollier E, Sarazin G, Prévot F, Jézéquel D (2007) Benthic response to shellfish farming in Thau lagoon: pore water signature. Estuar Coast Shelf Sci 72:406-419

Milligan TG, Kranck K (1991) Electroresistance particle size analyzers. In: Syvitski JPM (ed) Principles, methods, and application of particle size analysis. Cambridge University Press, New York, p 109-118

> Miron G, Landry T, Archambault P, Frenette B (2005) Effects of mussel culture husbandry practices on various benthic charcteristics. Aquaculture 250:138-154

Newell RIE (2004) Ecosystem influences of natural and cultivated populations of suspension-feeding bivave molluscs: a review. J Shellfish Res 23:51-61

Nilsson HC, Rosenberg R (2000) Succession in marine benthic habitats and fauna in response to oxygen deficiency: analysed by sediment-profile imaging and by grab samples. Mar Ecol Prog Ser 197:139-149

> Pedersen O, Binzer T, Borum J (2004) Sulphide intrusion in eelgrass (Zostera marina L.). Plant Cell Environ 27:595-602

Schaanning MT, Kupka Hansen P (2005) The suitability of electrode measurement for assessment of benthic organic impact and their use in a management system for marine fish farms. In: Hargrave BT (ed) Environmental effects of marine finfish aquaculture. Handbook Environ Chem 5, Springer, Berlin, p 381-408b

Shaw KR (1998) PEI Benthic Survey. Tech Rep Environ Sci 4

Statistics Canada (2005) Aquaculture statistics. Catalogue 23-222-XIE, Charlottetown, PEI, www.statcan.ca/cgi-bin/ downpub/listpub.cgi? catno=23-222-XIE2006000

Thermo Electron Corporation (2003) Orion silver/silver sulfide electrode instruction manual. Beverly, MA, p 1-67

Waite L, Grant J, Davidson J (2005) Bay-scale spatial growth variation of mussels Mytilus edulis in suspended culture, Prince Edward Island, Canada. Mar Ecol Prog Ser 297: 157-167

Wildish DJ, Akagi HM, Hamilton N, Hargrave BT (1999) A recommended method for monitoring sediments to detect organic enrichment from mariculture in the Bay of Fundy. Tech Rep Fish Aquat Sci 2286

> Wildish DJ, Hargrave BT, Pohle G (2001) Cost effective monitoring of organic enrichment resulting from salmon mariculture. ICES J Mar Sci 58:469-476

Wildish DJ, Akagi HM, Hargrave BT, Strain PM (2004) Interlaboratory calibration of redox potential and total sulphide measurements in interfacial marine sediments and the implications for organic enrichment assessment. Tech Rep Fish Aquat Sci 2546

Wilkinson L (2000) Systat 10.0 for Windows. SPSS, Chicago, IL

Submitted: May 15, 2007; Accepted: July 4, 2008

Proofs received from author(s): August 5, 2008 